\title{
Low-cost organic fertilizations and bioactivator for arugula-radish intercropping
}

\author{
Fernando Teruhiko Hata ${ }^{1 *}$, Maurício Ursi Ventura', Virgínia Sousa ${ }^{2}$, Gustavo Adolfo de Freitas Fregonezi ${ }^{3}$ \\ ${ }^{1}$ Agronomy Department, Universidade Estadual de Londrina, Londrina, Brazil, ${ }^{2}$ Extension of Niassa, Universidade do Rovuma, Province of \\ Niassa, Mozambique, ${ }^{3}$ Agronomy Department, Centro Universitário Filadélfia, Londrina, Brazil
}

\section{A B S T R A C T}

\begin{abstract}
The objective of this study was to evaluate the effects of boiled chicken manure doses (via fertigation), bokashi and Penergetic bioactivator on radish-arugula intercropping production variables. The treatments were control, Penergetic, Bokashi (9 g per plant), and boiled chicken manure $(\mathrm{BCM})$ on 2.5, 5.0, 7.5 and $10 \%$ concentrations in water, for fertigation. The following variables were analyzed: leaf biomass (LB), leaf length (LL), for both plants. Bulb fresh biomass (BB) and bulb volume (BV) variables for radish only. A completely randomized design with nine replicates was used for first and second crop cycles, and five replicates, for third crop cycle. All production variables were influenced by the treatments, except radish LL, on third cycle. Bokashi increased production variables of arugula and radish. Penergetic increased radish bulb biomass (two cycles, only) and bulb volume. BCM increased arugula biomass at $10 \%$ and radish bulb biomass at $7.5 \%$ on three crop cycles, and with $\mathrm{BCM}$ concentration at $5,7.5 \%$ and $10 \%$ bulb volume was increased (two crop cycles, only).
\end{abstract}

Keywords: Raphanus sativus; Eruca sativa; EM Bokashi; Boiled chicken manure; Agroecology

\section{INTRODUCTION}

Sustainable practices which allow high productivity, food free of pesticides residues, reduced costs for growers and low impacts on environment are now priority area in agriculture production systems. One of the most impactful agricultural practices is the soil fertilization. The overfertilization, commonly observed on horticultural crops, lead to waste of nutrients by leaching or volatilization (Zhao et al., 2019), and in most of cases increases diseases and pests incidence. Then, even with organic fertilizations, a rational utilization of resources is needed for a sustainable crop production.

Several studies have shown the organic source effects on radish or arugula development. Earthworm compost used in radish increases root biomass, compared to cattle manure (da Silva et al., 2006). On the other hand, in this cited study, radish plants fertilized with cattle manure presented higher root diameter $(18.71 \mathrm{~mm})$ and volume $\left(2.50 \mathrm{dm}^{3}\right.$ per plant) compared to earthworm compost 17.29 and 2.09 , respectively. Cattle manure alone or combined with filtercake provided a higher yield for arugula (Salles et al., 2017). Arugula fresh weight was higher for poultry litter fertilized plants than cattle manure, with 40 and $24 \mathrm{~T} \mathrm{ha}^{-1}$ yield, respectively (Pelá et al., 2017). Poultry litter also increased corn yield and soil fertility on a sandy soil (Barros et al., 2017).

The biofertilizer used as fertigation or foliar spray is one of the most important nutrient sources for organic farmers and its efficacy has not been yet well stablished. Foliar spraying of "Supermagro" biofertilizer increased number of fruits and total production of three strawberry varieties (Mazaro et al., 2013). In a study conducted with two lettuce varieties, were not observed fresh biomass or plant diameter improvements with foliar application of biofertilizer (Roel et al., 2007). On the other hand, biofertilizer used in fertigation drastically reduced the fresh biomass, number of leaves and foliar area in lettuce (Dias et al., 2009).

Bokashi is an organic amendment obtained by fermentation of manure and straws, rich in "efficient microorganisms" (EM), which increase the crop yield and protect the plant against pests and diseases (Higa and Wididana 1989). Vegetative growth of lettuce was significantly increased (Ferreira et al., 2017; Goulart et al., 2018) and reductions on Meloidogyne javanica infestation were observed with Bokashi 
application in lettuce (Ferreira et al., 2017). Bokashi and EM fertilizations increased fresh and dry matter of broccoli (Brassica oleracea L. var. italica) (Peralta-Antonio et al., 2019). Also, the cabbage (Brassica oleracea L. var. capitata) yield was increased (Xavier et al., 2019).

There are few studies with soil bioactivation with Penergetic. An increase of 7 and 21\% for common bean yield, for first and second production cycles, respectively, were achieved with Penergetic K and P (Cobucci et al., 2015). Increase of number of green beans pods, soybean (Penergetic K, only) and sugar beet yield were observed with Penergetic treatments (Jakiene et al., 2009; Brito et al., 2012; de Souza et al., 2017).

Chicken manure from intensive production farms is available in large amounts and may become a chemical and/or biological soil pollutant source if it is not correctly utilized. Farmers used to apply this manure as fertilizer; however, in Brazilian's organic production legislation the fresh manure use in leafy vegetables is restricted. Then, for reducing the abovementioned risks and for reusing of natural resources, chicken manure with thermal treatment may be used as an alternative for plant fertilization. In the present study, the boiled chicken manure (BCM), from laying hens, diluted in water was suggested, as fertigation option for organic farmers. Organic strawberry farmers have been using this approach (Galina et al., 2013); however, studies on other crops are still incipient. The greater advantages for BCM are: low-cost fertilization and its preparation is faster than biofertilizer (commonly fertilizer used in Brazilian organic farming), which demands at least one or two months, while $\mathrm{BCM}$ is ready to use in less than one-work day.

Thus, the objective of this study was to evaluate the effects of boiled chicken manure doses (via fertigation), Bokashi and Penergetic bioactivator on radish-arugula intercropping production variables.

\section{MATERIALS AND METHODS}

The experiments were conducted in three productive cycles, from February 2016 to December 2016, in a greenhouse located at Universidade Estadual de Londrina, PR (2319'44.5” S 5112'17.1” W; $585 \mathrm{~m}$ ), under organic management according to organic vegetable production Rule 10.831/2003 (Brazil, 2003) and inputs allowed by Normative proceeding 46/2011, regulated by Normative proceeding 17/2014 (Mapa, 2011; Mapa, 2014).

Arugula seedlings were transplanted on March $1^{\text {st }}$, September $6^{\text {th }}$, and November $4^{\text {th }}, 2016$ and harvested on April $1^{\text {st }}$, October $7^{\text {th }}$, and December $2^{\text {nd }}, 2016$, for the first, second and third cycles, respectively. Radish seeds were sown one week before rocket transplanting. Plants were grown on double line spaced $0.10 \mathrm{~m}$ and within a line $0.20 \mathrm{~m}$.

The substrate constituted a mixture of $16 \mathrm{~L}$ of soil, $10 \mathrm{~L}$ of sand, $9 \mathrm{~kg}$ of composted chicken bed, $1 \mathrm{~kg}$ of natural phosphate "Yoorin Master 1", $250 \mathrm{~g}$ of hydrated lime and $11 \mathrm{~L}$ of charred rice husk, for three cycles. Soil was a Red latosol (72.5\% clay; $20.2 \%$ silt and $7.3 \%$ sand; $\mathrm{pH} \mathrm{H}_{2} \mathrm{O}=5.90$; $\mathrm{P}=4.00 \mathrm{mg} \mathrm{dm}^{-3} ; \mathrm{K}^{+}=0.25 \mathrm{cmol}_{\mathrm{c}} \mathrm{dm}^{-3} ; \mathrm{Ca}^{+2}=4.0 \mathrm{cmol}_{\mathrm{c}} \mathrm{dm}^{-3}$; $\mathrm{Mg}^{+2}=1.5 \mathrm{cmol}_{\mathrm{c}} \mathrm{dm}^{-3} ; \mathrm{Al}^{+3}=0.0 ; \mathrm{H}+\mathrm{Al}^{+3}=2.60 \mathrm{cmol}_{\mathrm{c}}^{\mathrm{c}} \mathrm{dm}^{-3}$; and organic matter $-\mathrm{OM}=2.20 \%$ ). The substrate was packed in gutters $(0.15 \times 2.40 \mathrm{~m})$, bent to a $45^{\circ}$ angle, and sealed with plastic at the ends (Claro, 2013). The gutters were kept on benches $0.70 \mathrm{~m}$ high.

Treatments (Fig. 1) were: Control (water only); $200 \mathrm{~g}$ per gutter $\left(9\right.$ gperplant) of Bokashi compost $\left(\mathrm{N}=37.67 \mathrm{~g} \mathrm{~kg}^{-1} ; \mathrm{P}=\right.$ $14.36 \mathrm{~g} \mathrm{~kg}^{-1} ; \mathrm{K}^{+}=21.01 \mathrm{~g} \mathrm{~kg}^{-1} ; \mathrm{Ca}^{+2}=12.00 \mathrm{~g} \mathrm{~kg}^{-1} ; \mathrm{Mg}^{+2}=$ $\left.8.80 \mathrm{~g} \mathrm{~kg}^{-1}\right)$ in two applications: 15 days before $(100 \mathrm{~g})$ and 15 days after $(100 \mathrm{~g})$ arugula transplanting; bioactivator Penergetic $\mathbb{R} \mathrm{K}$ formulation $\left(1.5 \mathrm{~g} \mathrm{~L}^{-1}\right)$ applied to the substrate before planting and Penergetic ${ }^{\circledR} \mathrm{P}\left(1.5 \mathrm{~g} \mathrm{~L}^{-1}\right)$ sprayed on the plants 14 days after transplanting; and boiled chicken manure (BCM) on 2.5, 5.0, 7.5 and $10 \%$ concentrations in water, for fertigation. BCM were applied by fertigation once a day. BCM was prepared by boiling $30 \mathrm{~kg}$ of laying hens manure in $200 \mathrm{~L}$ of water for a period of $4 \mathrm{~h}$. The solution was then homogenized before being using. Chemical analysis shows the following composition for pure $\mathrm{BCM}$, after boiling process: $\mathrm{N}=3.80 \mathrm{~g} \mathrm{~kg}^{-1} ; \mathrm{P}=$ $0.01 \mathrm{~g} \mathrm{~kg}^{-1} ; \mathrm{K}^{+}=0.002 \mathrm{~g} \mathrm{~kg}^{-1} ; \mathrm{Ca}^{+2}=0.31 \mathrm{~g} \mathrm{~kg}^{-1}$ and $\mathrm{Mg}^{+2}=$ $0.11 \mathrm{~g} \mathrm{~kg}^{-1}$.

The following variables were analyzed: leaf biomass (LB), leaf length (LL), for both plants. Bulb fresh biomass (BB) and bulb volume (BV) variables for radish only.

A completely randomized design with nine replicates was used for first and second crop cycles, and five replicates, for third crop cycle. To verify the assumptions for analysis of variance, tests of variance homogeneity (F-test) and normality (Shapiro-Wilk test) were performed. If the assumptions were not met, then the data were square-root transformed. Analysis of variance was performed, and means were compared by Tukey's test $(\mathrm{p}<0.05)$. BioEstat 5.0 (Ayres, 2007) and SASM-Agri software packages (Canteri et al., 2001) were used.

\section{RESULTS}

All production variables were influenced by the treatments, except radish LL, on third cycle. For arugula, on Bokashi and BCM $10 \%$ treatments, LB obtained the higher means, for the three cycles (F: 50.68, 77.61, 6.86; $\mathrm{p}<0.05$, for first,

Emir. J. Food Agric • Vol 31 • Issue 10 • 2019 


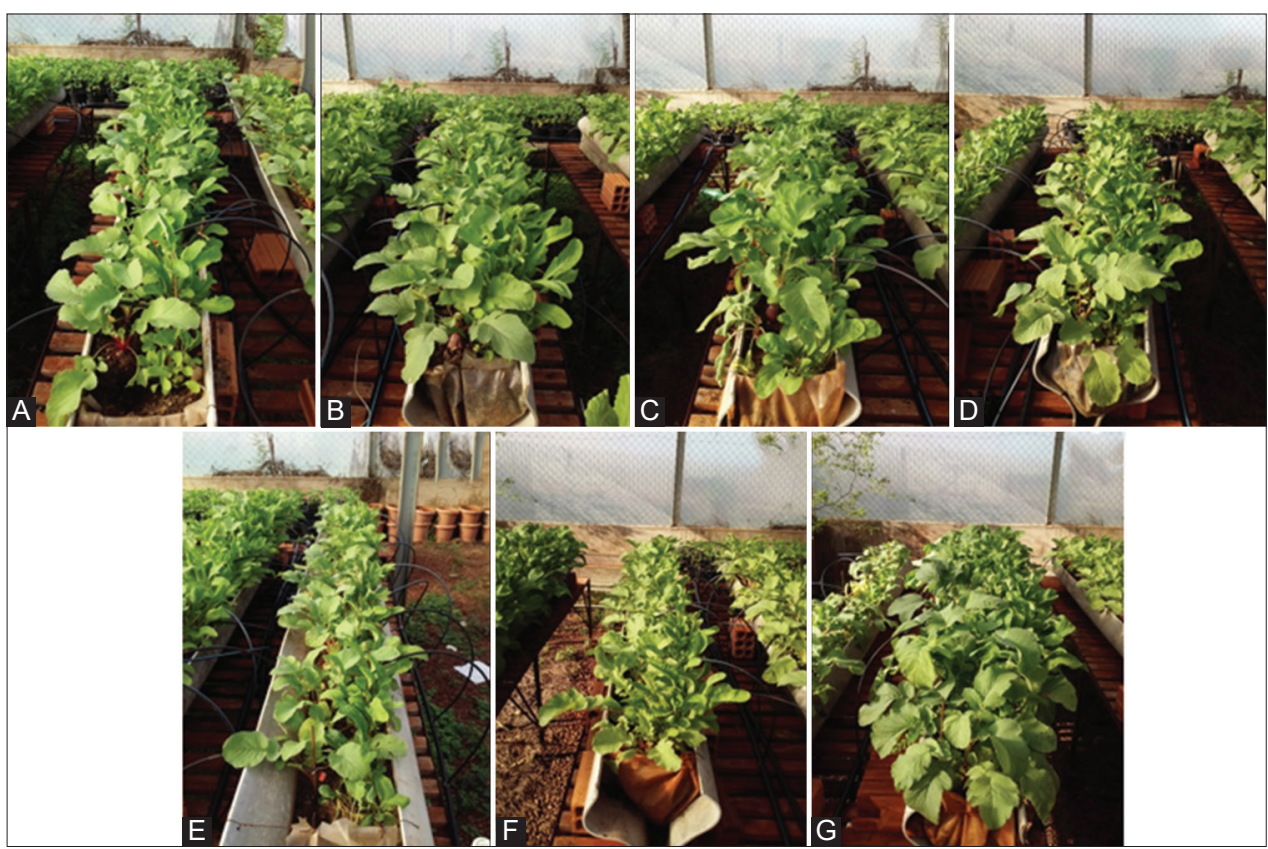

Fig 1. Arugula-radish intercropping submitted to four doses 2.5 (A), 5 (B), 7.5 (C), and 10\% (D) of boiled chicken manure (BCM), control (without fertilization) (E), Penergetic $(F)$ and Bokashi $(G)$ fertilization, cultivated in gutters in a greenhouse. Londrina, Brazil, 2016.

second and third cycles, respectively). For arugula LL, Bokashi obtained the higher means for the three cycles (F: 45.99, 44.61, 8.90; $\mathrm{p}<0.05$, for first, second and third cycles, respectively); BCM 10\% LL were higher than control treatment on cycle 3 , only.

Radish LB were higher for Bokashi, BCM 5, 7.5 and 10\%, compared to control on cycle 1 and 2 (F: 31.70, 8.95; $\mathrm{p}<0.05$, for first and second cycles, respectively); Penergetic also obtained higher values than control mean, but only on cycle 2. For cycle 1, Radish LL were higher for Bokashi, BCM 5, 7.5 and 10\%, compared to control (F: 41.51, $\mathrm{p}<0.05$ ); for cycle 2 , that variable was higher for Bokashi, BCM 5 and 7.5\%, compared to control (F: 11.27, p<0.05). All treatments obtained higher than control mean for $\mathrm{BB}$ variable on cycle 1, with highest mean on Bokashi treatment (F: 43.13, p<0.05). For second cycle, BB were higher for Bokashi, Penergetic, BCM 5 and $7.5 \%$, compared to control (F: 5.20, p<0.05). For third cycle, BCM 10\% obtained higher mean, compared to control (F: 17.72, $\mathrm{p}<0.05)$. For first cycle, radish BV were higher for Bokashi, Penergetic, BCM 5, 7.5 and 10\%, compared to control (F: 10.29, $\mathrm{p}<0.05)$. For second cycle, Bokashi, Penergetic, BCM 5 and 7.5\% obtained higher means than control (F: 6.00, $\mathrm{p}<0.05)$. For third cycle, Bokashi, Penergetic and BCM $10 \%$ obtained higher means than control (F: 11.30, $\mathrm{p}<0.05)$.

\section{DISCUSSION}

The present study shows that Bokashi promoted the greater benefits for both radish and arugula production variables for the three cycles (Tables 1, 2 and 3). Penergetic effects were more pronounced in radish than in arugula. Among $\mathrm{BCM}$ doses, for arugula, LB was influenced by the highest dose, only. For radish results often varies, however, for BB and $\mathrm{BV}$, in general, 7.5 and $10 \% \mathrm{BCM}$ presented the highest means, and for LB and LL variables, in general, 5, 7.5 and $10 \% \mathrm{BCM}$ presented higher than control means.

Studies on lettuce and arugula intercropping showed a higher plant height, number of leaves, fresh and dry biomass for organic arugula fertilized (with EM and other organic compounds) compared to arugula submitted to chemical fertilization; the same trend were observed for lettuce production variables (Oliveira et al., 2010). EM Bokashi prepared with goat or poultry manure presented a higher radish tuber yield and diameter than control or recommended non-organic fertilizations (Suthamathy and Seran, 2013). For lettuce, Bokashi fertilization promoted higher fresh biomass, head diameter and yield (Goulart et al., 2018). Bokashi is an organic amendment very rich in $\mathrm{N}, \mathrm{P}$ and $\mathrm{K}$ nutrients, which are essential to plant development. The high diversity of benefic microorganisms presented in Bokashi may benefit radish and arugula production variables as observed on the present study. However, more studies are necessary to explain what role Bokashi plays in soil fertility in terms of $\mathrm{N}$ availability and crop improvement (Quiroz and Céspedes, 2019).

The Penergetic increases were only observed on radish bulb variables (Table 3 ). There are few studies with that 
Table 1: Mean ( \pm Standard Error of Means) leaves biomass (LB) $(\mathrm{g})$ and leaves length (LL) (cm) in arugula cultivated under organic management and submitted to different concentrations of boiled chicken manure (BCM), Bokashi and Penergetic in a greenhouse, during three crop cycles. Londrina, Brazil, 2016

\begin{tabular}{|c|c|c|c|c|c|c|}
\hline \multirow[t]{2}{*}{ Treatment } & \multicolumn{3}{|c|}{ LB } & \multicolumn{3}{|c|}{ LL } \\
\hline & Cycle 1 & Cycle 2 & Cycle 3 & Cycle 1 & Cycle 2 & Cycle 3 \\
\hline Control & $3.02 \pm 0.47^{\text {cd }}$ & $4.00 \pm 0.80^{c}$ & $7.36 \pm 1.89^{c}$ & $19.67 \pm 1.23^{b}$ & $22.50 \pm 3.30^{\mathrm{bc}}$ & $22.67 \pm 3.08^{c}$ \\
\hline BCM 2.5\% & $2.89 \pm 0.35^{\mathrm{cd}}$ & $4.41 \pm 0.58^{c}$ & $9.49 \pm 2.31^{b c}$ & $20.13 \pm 1.73^{b}$ & $22.72 \pm 1.37^{\mathrm{bc}}$ & $24.25 \pm 2.71^{c}$ \\
\hline BCM 5\% & $2.78 \pm 0.56^{\mathrm{cd}}$ & $5.23 \pm 0.94^{\mathrm{bc}}$ & $10.47 \pm 2.43^{\mathrm{abc}}$ & $19.78 \pm 1.56^{b}$ & $21.17 \pm 3.02^{c}$ & $26.63 \pm 2.26^{\mathrm{bc}}$ \\
\hline BCM $7.5 \%$ & $3.64 \pm 0.91^{b c}$ & $5.57 \pm 0.85^{\mathrm{bc}}$ & $8.67 \pm 1.95^{\mathrm{bc}}$ & $21.50 \pm 1.85^{b}$ & $25.00 \pm 1.37^{b}$ & $23.38 \pm 2.83^{c}$ \\
\hline BCM 10\% & $4.13 \pm 0.96^{b}$ & $6.17 \pm 0.81^{b}$ & $13.05 \pm 3.20^{\mathrm{a}}$ & $21.38 \pm 1.30^{b}$ & $23.56 \pm 2.59^{b c}$ & $28.38 \pm 2.26^{\mathrm{ab}}$ \\
\hline Penergetic & $2.45 \pm 0.69^{d}$ & $4.16 \pm 0.97^{c}$ & $7.81 \pm 1.17^{c}$ & $20.11 \pm 1.45^{b}$ & $21.50 \pm 1.60^{\circ}$ & $24.75 \pm 3.06^{\mathrm{bc}}$ \\
\hline Bokashi & $7.54 \pm 0.81^{\mathrm{a}}$ & $12.19 \pm 1.57^{\mathrm{a}}$ & $11.55 \pm 1.37^{\mathrm{ab}}$ & $32.14 \pm 3.08^{a}$ & $35.44 \pm 1.36^{a}$ & $30.50 \pm 1.77^{a}$ \\
\hline CV & 18.87 & 16.33 & 21.83 & 8.17 & 9.09 & 10.07 \\
\hline $\mathrm{F}$ & 50.68 & 77.61 & 6.86 & 45.99 & 44.61 & 8.90 \\
\hline
\end{tabular}

CV: Coefficient of variation; Means followed by the same letter in the same column did not differ significantly from each other (Tukey test, $P>0.05$ )

Table 2: Mean ( \pm Standard Error of Means) leaves biomass (LB) (g) and leaves length (LL) (cm) in radish cultivated under organic management and submitted to different concentrations of boiled chicken manure (BCM), Bokashi and Penergetic in a greenhouse, during three crop cycles. Londrina, Brazil, 2016

\begin{tabular}{|c|c|c|c|c|c|c|}
\hline \multirow[t]{2}{*}{ Treatment } & \multicolumn{3}{|c|}{ LB } & \multicolumn{3}{|c|}{ LL } \\
\hline & Cycle 1* & Cycle 2 & Cycle 3 & Cycle 1 & Cycle 2 & Cycle 3 \\
\hline Control & $9.74 \pm 2.93^{d}$ & $9.56 \pm 1.67^{d}$ & $18.80 \pm 1.30^{\mathrm{ab}}$ & $18.78 \pm 1.37^{e}$ & $19.06 \pm 1.81^{c}$ & $16.60 \pm 1.34^{a}$ \\
\hline BCM 2.5\% & $14.72 \pm 3.70^{\text {cd }}$ & $12.67 \pm 4.12^{\mathrm{cd}}$ & $17.00 \pm 2.34^{b}$ & $21.89 \pm 3.06^{\mathrm{de}}$ & $19.39 \pm 2.45^{c}$ & $17.00 \pm 2.35^{a}$ \\
\hline BCM 5\% & $19.68 \pm 4.44^{\mathrm{bc}}$ & $18.89 \pm 3.76^{\mathrm{ab}}$ & $19.20 \pm 2.28^{\mathrm{ab}}$ & $25.33 \pm 2.06^{\mathrm{bc}}$ & $23.83 \pm 1.62^{\mathrm{ab}}$ & $19.20 \pm 2.28^{a}$ \\
\hline BCM $7.5 \%$ & $26.04 \pm 6.48^{b}$ & $17.56 \pm 5.36^{\mathrm{abc}}$ & $18.20 \pm 2.59^{a b}$ & $27.89 \pm 2.37^{b}$ & $22.44 \pm 3.28^{\mathrm{ab}}$ & $17.20 \pm 1.48^{a}$ \\
\hline BCM 10\% & $16.79 \pm 4.98^{c}$ & $14.89 \pm 2.67^{\mathrm{abc}}$ & $22.70 \pm 3.1^{a}$ & $22.89 \pm 1.90^{\mathrm{cd}}$ & $21.22 \pm 1.56^{\mathrm{bc}}$ & $20.40 \pm 1.52^{\mathrm{a}}$ \\
\hline Penergetic & $15.82 \pm 4.18^{c}$ & $13.56 \pm 2.79^{\mathrm{bcd}}$ & $17.40 \pm 1.52^{b}$ & $19.89 \pm 1.36^{\text {de }}$ & $19.28 \pm 1.68^{c}$ & $17.40 \pm 1.52^{\mathrm{a}}$ \\
\hline Bokashi & $40.20 \pm 8.79^{a}$ & $20.44 \pm 5.73^{a}$ & $17.60 \pm 2.88^{b}$ & $33.22 \pm 3.42^{\mathrm{a}}$ & $24.94 \pm 1.84^{a}$ & $17.60 \pm 2.88^{a}$ \\
\hline CV & 11.98 & 11.93 & 12.69 & 9.63 & 9.86 & 11.08 \\
\hline$F$ & 31.7 & 8.95 & 3.3 & 41.51 & 11.27 & 2.38 \\
\hline
\end{tabular}

CV: Coefficient of variation; Means followed by the same letter in the same column did not differ significantly from each other (Tukey test, $\mathrm{P}>0.05)$. ${ }^{*}$ Square root transformation of the data was performed

Table 3: Mean ( \pm Standard Error of Means) bulb fresh biomass $(\mathrm{BB})(\mathrm{g})$ and bulb volume (BV) (cm $\left.{ }^{3}\right)$ in radish cultivated under organic management and submitted to different concentrations of boiled chicken manure (BCM), Bokashi and Penergetic in a greenhouse, during three cycles. Londrina, Brazil, 2016

\begin{tabular}{|c|c|c|c|c|c|c|}
\hline \multirow[t]{2}{*}{ Treatment } & \multicolumn{3}{|c|}{ BB } & \multicolumn{3}{|c|}{ BV } \\
\hline & Cycle 1* & Cycle 2 & Cycle 3 & Cycle 1* & Cycle 2 & Cycle 3* \\
\hline Control & $18.23 \pm 4.18^{d}$ & $12.67 \pm 7.42^{c}$ & $12.80 \pm 4.82^{\mathrm{bc}}$ & $93.68 \pm 25.32^{d}$ & $98.92 \pm 62.50^{b}$ & $90.48 \pm 48.00^{\circ}$ \\
\hline BCM 2.5\% & $33.72 \pm 8.44^{c}$ & $18.89 \pm 8.84^{\mathrm{bc}}$ & $10.20 \pm 6.65^{c}$ & $171.07 \pm 59.29^{c d}$ & $231.25 \pm 110.69^{a b}$ & $109.64 \pm 58.26^{c}$ \\
\hline BCM 5\% & $39.52 \pm 5.48^{c}$ & $32.89 \pm 14.36^{\mathrm{ab}}$ & $21.60 \pm 13.22^{\mathrm{bc}}$ & $275.59 \pm 86.26^{a b c}$ & $312.75 \pm 152.20^{a}$ & $174.25 \pm 120.14^{\text {bc }}$ \\
\hline BCM $7.5 \%$ & $58.88 \pm 11.16^{b}$ & $35.78 \pm 15.44^{\mathrm{ab}}$ & $30.40 \pm 11.26^{b}$ & $312.30 \pm 141.28^{a b}$ & $319.85 \pm 125.89^{a}$ & $186.73 \pm 43.19^{b c}$ \\
\hline BCM 10\% & $44.07 \pm 10.98^{c}$ & $26.89 \pm 10.06^{\mathrm{abc}}$ & $61.40 \pm 8.82^{\mathrm{a}}$ & $288.56 \pm 149.40^{\mathrm{abc}}$ & $228.79 \pm 105.57^{\mathrm{ab}}$ & $563.09 \pm 135.64^{a}$ \\
\hline Penergetic & $40.76 \pm 8.06^{c}$ & $31.11 \pm 9.44^{\mathrm{ab}}$ & $29.60 \pm 7.40^{\mathrm{b}}$ & $212.70 \pm 73.66^{\mathrm{bc}}$ & $272.66 \pm 86.19^{a}$ & $375.21 \pm 167.36^{\mathrm{ab}}$ \\
\hline Bokashi & $87.66 \pm 19.21^{a}$ & $38.44 \pm 16.97^{a}$ & $24.50 \pm 8.05^{\mathrm{bc}}$ & $366.64 \pm 115.98^{a}$ & $368.11 \pm 81.64^{a}$ & $311.65 \pm 146.09^{a b}$ \\
\hline $\mathrm{CV}$ & 9.46 & 43.71 & 33.05 & 18.12 & 40.94 & 22.70 \\
\hline$F$ & 43.13 & 5.20 & 17.72 & 10.29 & 6.00 & 11.30 \\
\hline
\end{tabular}

CV: Coefficient of variation; Means followed by the same letter in the same column did not differ significantly from each other (Tukey test, $\mathrm{P}>0.05) .{ }^{*}$ Square root transformation of the data was performed

soil bioactivator in literature. Previously, sugar beetroot yield was increased by $17.2 \%$ with Penergetic Jakiene et al., 2009). Common bean yield was increased with Penergetic bioactivator (Cobucci et al., 2015). On the other hand, soybean physiological variables (seedling length, weight of 1000 seeds, green and dry matter of plants) were not affected by bioactivator (de Camargo et al., 2018). These shows that results with bioactivator may vary and more studies to confirm its efficacy in increasing crops yield or production variables must have to be realized.

$\mathrm{BCM}$ is not as rich as Bokashi in nutrient content, which may explain the greater response, mainly observed on arugula, in favor of Bokashi. On the other hand, the advantage for $\mathrm{BCM}$ is the low production costs for preparing this product. Farmers which have chicken rearing could collect its manure and produce $\mathrm{BCM}$ with no additional cost. 


\section{CONCLUSIONS}

Bokashi increased arugula and radish yields. $\mathrm{BCM}$ increased arugula biomass at 10\%. BCM concentrations increased radish bulb biomass at $7.5 \%$ on three crop cycles and at 5 , $7.5 \%$ and $10 \%$ bulb volume was increased (two crop cycles, only). Penergetic increased radish bulb biomass (two crop cycles, only) and bulb volume.

\section{ACKNOWLEDGMENTS}

We would like to thank to the research funding agencies Conselho Nacional de Desenvolvimento Científico e Tecnológico - CNPq and Coordenação de Aperfeiçoamento de Pessoal de Nível Superior - CAPES, for the scholarships granted.

\section{Disclosure statement}

The authors declare that there is no conflict of interest regarding the publication of this manuscript.

\section{Authors' contributions}

FTH designed and performed the experiments, analyzed the results and prepared the manuscript. MUV designed the experiments and revised the manuscript. VS performed the experiments and prepared the manuscript. GAFF designed and performed the experiments.

\section{REFERENCES}

Ayres, M. 2007. BioEstat 5.0: Aplicações Estatísticas nas Áreas das Ciências Biológicas e Médicas. Belém: Sociedade Civil Mamirauá. $5^{\text {th }}$ ed. Conselho Nacional de Desenvolvimento Científico e Tecnológico, Brasília.

Barros, J. S., J. C. Medeiros, J. D. Rosa, J. J. J. Lacerda, D. C. de Sousa and M. S. H. Mafra. 2017. Corn yield in sandy soil fertilized with poultry litter. Emir. J. Food Agric. 29(12): 921-926.

Brazil. 2003. Lei No. 10831, de 23 de Dezembro de 2003. Available from: http://www.planalto.gov.br/ccivil_03/LEIS/2003/L10.831. $\mathrm{htm}$. [Last accessed on 2019 Oct 24].

Brito, O.R., F. K. Dequech and R. M. Brito. 2012. Use of Penergetic Products $\mathrm{P}$ and $\mathrm{K}$ in the Snap Bean Production. Vol. 55. Annual Report of the Bean Improvement Cooperative, Washington, D.C, pp. 279-280.

Canteri, M. G., R. A. Althaus, J. S. V. Filho, E. A. Giglioti and C.V. Godoy. 2001. SASM Agri: Sistema para análise e separação de médias em experimentos agrícolas pelos métodos Scott-Knott. Tukey e duncan. Rev. Bras. Agrocomputação. 1: 18-24.

Cobucci, T., A. S. Nascente and D. P. Lima. 2015. Adubação fosfatada e aplicação de Penergetic na produtividade do feijoeiro comum. Agrarian. 8(30): 358-368.

Claro, S.A. 2013. Leitos e substratos para produção orgânica de hortaliças controle da murcha bacteriana. Editora Agrolivros, Guaíba, p. 280.

da Silva, C. J., C. C. Costa, C. Duda, P. C. Timossi and I. C. Leite. 2006. Crescimento e produção de rabanete cultivado com diferentes doses de húmus de minhoca e esterco bovino. Rev.
Ceres. 53(305): 25-30.

de Camargo, J. N. C., T. L. Mendes, F. K. A. Cantareli, E. S. Santana and E. E. de França. 2018. Adubação com bioativador, organomineral e NPK em latossolo vermelho-amarelo na qualidade fisiológica de soja. Rev. Agric. Neotropical. 5(4): 7-12.

de Souza, A. A., F. Z. de Almeida and O. Alberton. 2017. Growth and yield of soybean with Penergetic application. Sci. Agraria. 18(4): 95-98.

Dias, N. D. S., A. A. F. de Brito, O. N. D. Neto, R. B. de Lira, R. F. de Brito. 2009. Produção de alface hidropônica utilizando biofertilizante como solução nutritiva. Rev. Caatinga. 22(4): 158-162.

Ferreira, J. C., I. Hernandes, O. D. Brito, M. R. Cardoso and C. R. Dias-Arieira. 2017. Dosages of bokashi in the control of Meloidogyne javanica in lettuce, in greenhouse. Hortic. Bras. 35(2): 224-229.

Galina, J., L. Ilha and J. Pagnoncelli. 2013. Cultivo orgânico do morangueiro em substrato. Cad. Agroecol. 8(2): 14879.

Goulart, R. G. T., C. A. dos Santos, C. M. de Oliveira, E. S. P. Costa, F. A. de Oliveira, N. F. de Andrade and M. G. F. do Carmo. 2018. Desempenho agronômico de cultivares de alface sob adubação orgânica em Seropédica, RJ. Rev. Bras. Agropec. Sustentável. 8(3): 66-72.

Jakiene, E., V. Venskutonis and V. Liakas. 2009. Fertilization of sugar beetroot with ecological fertilizers. Agron. Res. 7: 269-276.

Mapa-Ministério da Agricultura, Pecuária e Abastecimento. 2011. Instrução Normativa MAPA 46/2011. Available from: http://www. agricultura.gov.br/assuntos/insumos-agropecuarios/insumosagricolas/agrotoxicos/legislacao/arquivos-de-legislacao/ in-46-2011-regulamento-tecnico-para-sistemas-organicos-deproducao. [Last accessed on 2019 Oct 24].

Mapa-Ministério da Agricultura, Pecuária e Abastecimento. 2014. Instrução Normativa MAPA 17/2014. Available from: http:// www.agricultura.gov.br/assuntos/sustentabilidade/organicos/ legislacao/portugues/instrucao-normativa-no-17-de-18-dejunho-de-2014.pdf/view. [Last accessed on 2019 Oct 24].

Mazaro, S.M., M. M. Caprini, I. Citadin, D. Paulus and A. de Gouvea. 2013. Produção e qualidade de morangueiro sob diferentes concentrações de calda bordalesa, sulfocálcica e biofertilizante supermagro. Semin Cienc. Agrar. 34(6): 3285-3294.

Oliveira, E. Q., R. J. Souza, M. C. M. Cruz, V. B. Marques and A. C. França. 2010. Produtividade de alface e rúcula, em sistema consorciado, sob adubação orgânica e mineral. Hortic. Bras. 28(1): 36-40.

Pelá, A., G. S. S. Júnior, R. C. D. da Silva, C. S. Silva and G. M. Pelá. 2017. Produção e teor de nitrato em rúcula sob adubação orgânica com cama de frango e esterco bovino. Rev. Verde Agroecol. Desenvolv. Sustentável. 12(1): 48-54.

Peralta-Antonio, N., G. B. de Freitas, M. Watthier and R. H. S. Santos. 2019. Compost, bokashi y microorganismos eficientes: Sus beneficios en cultivos sucesivos de brócolis. Idesia. 37(2): 59-66.

Quiroz, M. and C. Céspedes. 2019. Bokashi as an amendment and source of nitrogen in sustainable agricultural systems: A review. J. Plant Nutr. Soil Sci. 19(1): 237-248.

Roel, A. R., L. A. K. Leonel, S. P. Favaro, M. Zatarim, C. M. V. Momeso and M. V. Soares. 2007. Avaliação de fertilizantes orgânicos na produção de alface em Campo Grande, MS. Sci. Agraria. 8(3): 325-329.

Salles, J. S., F. Steiner, J. E. P. Abaker, T. S. Ferreira and G. L. M. Martins. 2017. Resposta da rúcula à adubação orgânica com diferentes compostos orgânicos. Rev. Agric. Neotrop. 4(2): $35-40$. 
Suthamathy, N. and T. H. Seran. 2013. Residual effect of organic manure EM Bokashi applied to proceeding crop of vegetable cowpea (Vigna unguiculata) on succeeding crop of radish (Raphanus sativus). Res. J. Agric. For. Sci. 1(1): 2-5.

Xavier, M. C. G., C. A. dos Santos, E. S. P. Costa and do Carmo M. G. F.
2019. Produtividade de repolho em função de doses de bokashi. Rev. Agric. Neotrop. 6(1): 17-22.

Zhao, H., X. Li and Y. Jiang. 2019. Response of nitrogen losses to excessive nitrogen fertilizer application in intensive greenhouse vegetable production. Sustainability-Basel. 11(6): 1513. 